\title{
Tingkat Populasi Jamur Tanah akibat Perlakuan Fungisida Mankozeb di Pertanaman Sayur Kubis (Brassica oleracea var.capitata) Kecamatan Modoinding, Kabupaten Minahasa Selatan, Sulawesi Utara (The Population Level of Soil Fungi under Mankozeb Fungicides Application in the Cabbage (Brassica oleracea var.capitata) Plantation of Modoinding Subdistrict, South Minahasa District, North Sulawesi)
}

\author{
Isna Lestari'), Stella D. Umboh'), Johanis J. Pelealu') \\ 1)Program Studi Biologi FMIPA UNSRAT Manado, 95115 \\ ${ }^{\star}$ Email korespondensi: isna.lestari8@gmail.com
}

Diterima 23 Januari 2018, diterima untuk dipublikasi 28 Februari 2018

\begin{abstract}
Abstrak
Dalam pengembangan sayuran kubis (Brassica oleracea var.capitata) petani sering menggunakan pestisida secara berlebihan. Penggunaan pestisida secara berlebihan tersebut berdampak pada sterilisasi ekosistem tanah, yang mengakibatkan penurunan tingkat populasi jamur tanah. Tujuan penelitian ini yaitu untuk menganalisis tingkat populasi jamur tanah akibat paparan fungisida Mankozeb di pertanaman sayuran kubis. Penelitian ini dilakukan dengan mengisolasi jamur pada tanah di sayur kubis Kecamatan Modoinding, Kabupaten MInahasa Selatan menggunakan pengenceran bertingkat, kemudian dilanjutkan dengan metode Total Plate Count (TPC) untuk menghitung jumlah koloni. Hasil penelitian menunjukkan bahwa fungisida Mankozeb mempengaruhi jumlah populasi jamur tanah, dilihat dari sedikitnya jumlah spesies yang ditemukan. Dari 6 famili dengan 11 jenis yang ditemukan, jamur tanah yang memiliki koloni terbesar adalah isolat KJ5 (Penicillium sp.) sebesar 270 koloni dengan jumlah spora $5.9 \times 10^{-6} \mathrm{CFU} / \mathrm{mL}$ dan terendah pada isolat $\mathrm{KJ} 3$ (Trichoderma harzianum) sebesar 2 koloni dengan jumlah spora $10^{-7} \mathrm{CFU} / \mathrm{mL}$.

Kata kunci : Kubis, jamur tanah, Mankozeb, koloni, TPC, CFU/mL
\end{abstract}

\begin{abstract}
Farmers often use excessive pesticides in the plantation of cabbage (Brassica oleracea var. capitata). The excessive use of pesticides resulted in sterilization of soil ecosystems and followed by the decrease the level of soil fungal population. The purpose of this study was to analyze the population level of soil fungi after exposure the cabbage plantation to Mankozeb fungicide. This research was conducted by isolating the fungi from the soil in cabbage plantation in Modoinding subdistrict, South Minahasa District using a multilevel dilution and followed by Total Plate Count (TPC) method to calculate the fungi colony number. The results showed that Mankozeb fungicide affected the population of soil fungi, based on the limited number of identified fungi species. There were 6 families and 11 species of soil fungi. The largest number was in KJ5 (Penicillium sp.), i.e. 270 colonies and the spore number was $5.9 \times 10^{-6} \mathrm{CFU} / \mathrm{mL}$. The lowest number was KJ3 (Trichoderma harzianum), i.e. 2 colonies and the number of spores was $10^{-7} \mathrm{CFU} / \mathrm{mL}$.

Keywords : Cabbage, soil fungi, Mankozeb, colony, TPC, CFU/mL
\end{abstract}




\section{PENDAHULUAN}

Kubis (Brassica oleracea var. capitata) merupakan salah satu komoditas yang dikembangkan di Sulawesi Utara, tepatnya di Kecamatan Modoinding Kabupaten Minahasa Selatan. Dalam pengembangannya petani sering menggunakan pestisida untuk mengendalikan serangan hama dan penyakit. Salah satu Jenis pestisida yang digunakan oleh petani yaitu Manzate 82 WP yang memiliki bahan aktif Mankozeb. Fungisida ini digunakan untuk mengendalikan penyakit bercak daun yang disebabkan oleh jamur Alternaria brassicae.

Penggunaan fungisida untuk pengendalian penyakit sayur-sayuran terutama pada sayuran kubis di Sulawesi Utara sudah sangat berlebihan baik dari segi dosis maupun jumlah perlakuan (Sembel, 2014). Dampak samping aplikasi pestisida di lahan tanaman kubis adalah adanya residu yang tertinggal di dalam tanah. Menurut Wardana (2001), penggunaan pestisida merupakan faktor eksternal pencemaran tanah, sehingga semakin banyak tanaman kubis disemprot dengan pestisida maka akan berpengaruh terhadap akumulasi residu pada tanah sehingga dapat membahayakan mikroorganisme tanah.

Penggunaan pestisida berlebih berdampak pada tanah sehingga terjadi sterilisasi ekosistem tanah, sehingga tingkat populasi bakteri dan jamur di dalam tanah mengalami penurunan. Tingkat populasi jamur tanah merupakan banyaknya jumlah jenis jamur tanah yang hidup pada suatu lahan. Menurut Hidersah et al. (2014), efek penting yang disebabkan oleh pestisida antara lain perubahan keseimbangan ekologi mikroba tanah dan perubahan jumlah populasi mikroba tanah.

Khan (2003) mengatakan bahwa penggunaan pestisida telah merusak kesimbangan alami pada tanah pertanian dan menyebabkan penurunan kelimpahan keanekaragaman hayati organisme tanah terutama jamur tanah. Menurut Umboh (2016), akumulasi senyawa bahan aktif pestisida seperti fungisida Antracol di dalam tanah dapat menyebabkan penghambatan pertumbuhan jamur tanah tersebut. Menurut Greaves dan Malkomes dalam Noya (2004), perubahan populasi mikroorganisme tanah dapat digunakan untuk memprediksi dampak penggunaan pestisida terhadap tanah.

Dari uraian tersebut di atas, dapat dikatakan bahwa dampak penggunaan fungisida Mankozeb pada tanaman kubis sangat merugikan, khususnya pada mikroba tanah. Di Kecamatan Modoinding, informasi tentang dampak residu fungisida Mankozeb terhadap mikroba tanah khususnya jamur tanah pada tanaman sayur kubis belum ada. Masalah-masalah di atas mengenai pengaruh residu fungisida terhadap resistensi jamur tanah sampai saat ini belum dapat ditanggulangi, sehingga perlu diadakannya penelitian tentang tingkat populasi jamur tanah terhadap fungisida Mankozeb di pertanaman sayur kubis.

\section{METODE}

\section{Waktu dan Tempat}

Penelitian ini dilakukan pada bulan Oktober sampai Desember 2017, yang dilaksanakan di Laboratorium Mikrobiologi Jurusan Biologi Fakultas Matematika dan IImu Pengetahuan Alam, Universitas Sam Ratulangi, Manado.

\section{Alat dan Bahan}

Alat dan bahan yang digunakan yaitu, plastik ziplock, timbangan analitik, aluminium foil, hotplate, tabung reaksi, suntik (10 $\mathrm{mL})$, vortex, cawan petri $(10 \mathrm{~cm})$, jarum ose, kaca objek dan kaca 
penutup, parafilm, mikroskop, autoklaf, laminar, bor tanah, penggaris, sampel tanah, Potato Dextrose Agar (PDA), akuades, alkohol $70 \%$, kotrimoksazol, dan metilen blue.

\section{Penghitungan Koloni}

Sampel tanah yang diambil di pertanaman kubis dibawa ke Laboratorium Mikrobiologi Jurusan Biologi Fakultas Matematika dan IImu Pengetahuan Alam, Universitas Sam Ratulangi, Manado untuk dilakukan isolasi. Koloni jamur dalam cawan petri yang tumbuh dari hasil isolasi dihitung menggunakan metode Total Plate Count (TPC), dengan menganggap setiap sel yang ada dapat hidup dan berkembang menjadi satu koloni. Untuk menghitung jumlah spora per $1 \mathrm{~mL}$ sampel dihitung berdasarkan Hogg
(2005) dalam Fenina (2012) dengan rumus:

$\mathrm{CFU} / \mathrm{mL}=\frac{\text { Jumlah Rata-Rata Koloni }}{\text { Volume Inokulum x Faktor Pengenceran }}$

\section{HASIL DAN PEMBAHASAN}

Dalam penelitian ini, tingkat populasi jamur tanah dapat diketahui dengan metode pengenceran bertingkat. Dari 5 sampel tanah yang diuji dengan 4 seri pengenceran, diperoleh koloni tertinggi terdapat pada isolat jamur $\mathrm{KJ} 5$ sebesar 60 koloni yang tumbuh pada sampel tanah E pada pengenceran ke 3 (10 $\left.{ }^{4}\right)$ yang tumbuh dari 11 jenis jamur tanah. koloni jamur tanah yang tumbuh dalam media PDA disetiap pengenceran dapat dilihat pada Gambar 1 dan Tabel 1

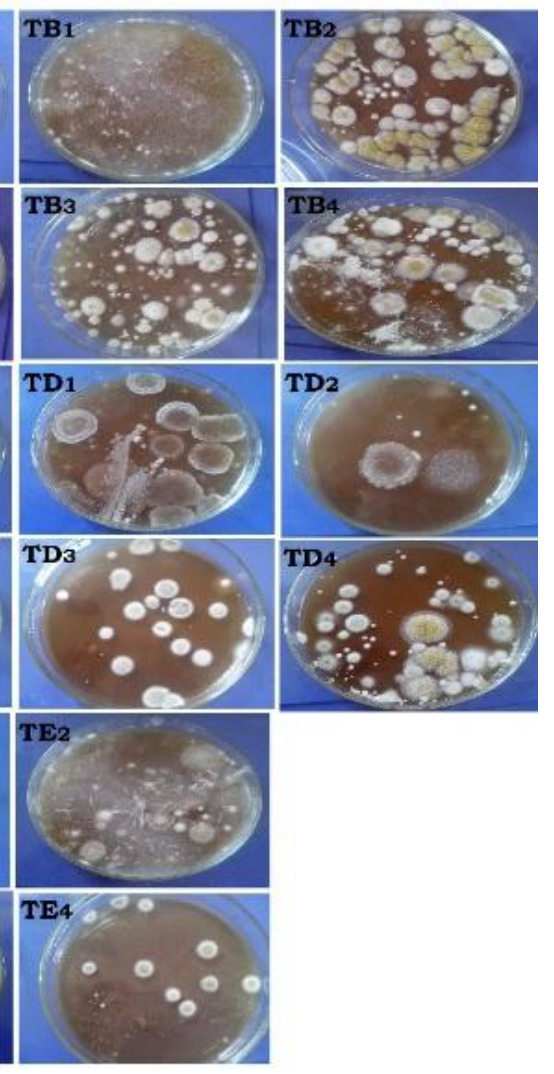

Gambar 1. Koloni jamur tanah yang tumbuh pada 5 sampel tanah dengan 4 seri pengenceran 
Tabel 1. Hasil identifikasi isolat-isolat jamur tanah dari 5 sampel tanah di pertanaman kubis (famili dan spesies jamur tanah)

\begin{tabular}{|c|c|c|c|}
\hline $\begin{array}{l}\text { SAMPEL TANAH DAN } \\
\text { PENGENCERAN }\end{array}$ & ISOLAT & SUKU & JENIS \\
\hline $\begin{array}{c}\text { TA1, TA3, TB1, TB4, TC1, } \\
\text { TD2, TD4, TE1 }\end{array}$ & KJ1 & Chaetomiaceae & Humicola fuscoatra \\
\hline $\begin{array}{c}\text { TA3, TA4, TD1, TD2, TD4, } \\
\text { TE1, TE2 }\end{array}$ & $\mathrm{KJ} 2$ & Sordariaceae & Chrysonilia sitophila \\
\hline TC1, TD2 & KJ3 & Hypocreaceae & Thricoderma harzianum \\
\hline $\begin{array}{l}\text { TA2, TA4, TB2, TB3, TB4, } \\
\text { TC2, TC4, TE2 }\end{array}$ & KJ4 & Trichocomaceae & Aspergillus sydowii \\
\hline $\begin{array}{l}\text { TB1, TB2, TB3, TB4, TD2, } \\
\text { TD3, TD4, E1, E2, E3, E4 }\end{array}$ & KJ5 & Trichocomaceae & Penicillium sp. \\
\hline $\begin{array}{c}\text { TB2, TB3, TC2, TC3, TC4, } \\
\text { TD4, TE3 }\end{array}$ & KJ6 & Mucoraceae & Mucor hiemalis \\
\hline TA4, TB3 & KJ7 & Trichocomaceae & Penicillium citrinum \\
\hline TD3 & KJ8 & Nectriaceae & Fusarium oxysporum \\
\hline TC2, TD4, & KJ9 & Trichocomaceae & Aspergillus fumigatus \\
\hline TD4 & KJ10 & Trichocomaceae & Aspergillus terreus \\
\hline TD3, TD4 & KJ11 & Trichocomaceae & Aspergillus flavus \\
\hline
\end{tabular}

\footnotetext{
Keterangan:

TA = Tanah Sampel A

TB $=$ Tanah Sampel B

TC = Tanah Sampel C

TD = Tanah Sampel D

$\mathrm{TE}=$ Tanah Sampel E

1 = Pengenceran $10^{-2}$

2 = Pengenceran $10^{-3}$

$3=$ Pengenceran $10^{-4}$

4 = Pengenceran $10^{-5}$

$\mathrm{KJ}=$ Koloni Jamur
}

Bervariasinya jenis jamur tanah yang diisolasi dan diidentifikasi diduga dipengaruhi oleh jenis tanaman yang dibudidayakan (Rao, 1994). Pada penelitian ini, luas lahan yang digunakan hanya berukuran 10 $\mathrm{m}$ x $10 \mathrm{~m}$ yang memungkinkan terbatasnya jumlah jamur yang diperoleh. Hal ini sesuai dengan pendapat dari Wirakusumah (2003) dalam Pangestu (2009), yang mengatakan bahwa dinamika jamur ditentukan oleh jumlah spesies dan angka kekayaan spesies ditentukan oleh luas dan lokasi tempat komunitas berada.

Pada 5 sampel tanah yang diencerkan dengan 4 seri pengenceran yaitu: pengenceran 1 $\left(10^{-2}\right), 2\left(10^{-3}\right), 3\left(10^{-4}\right)$, dan $4\left(10^{-5}\right)$, jumlah koloni terbanyak terdapat pada KJ5 (Penicillium sp.) (270 koloni) diikuti oleh $\mathrm{KJ} 4$ ( $A$. sydowii) (70 koloni) dan terendah pada 3 jenis jamur yaitu KJ3 (Tricoderma harzianum), KJ8 (Fusarium oxysporum), dan $\mathrm{KJ} 10$ (A. terreus) masing-masing 2 koloni jamur yang tumbuh. Hasil ini mempengaruhi rerata jumlah spora CFU/mL berdasarkan perhitungan dengan metode Total Plate Count (TPC). Jumlah spora tertinggi pada jamur KJ5 (Penicillium sp.) (5,9 $910^{-6}$ $\mathrm{CFU} / \mathrm{mL}$ ) dan jumlah spora yang terendah terdapat pada jamur KJ3 ( $T$. 
harzianum $) \quad\left(0,1 \times 10^{-6} \quad \mathrm{CFU} / \mathrm{mL}\right)$, sedangkan yang memiliki nilai kisaran jumlah spora yang sama terdapat pada 4 jenis jamur yaitu: $\mathrm{KJ} 8$ ( $F$. oxysporum), KJ9 (A. fumigatus), KJ10 (A. terreus), dan $\mathrm{KJ} 11$ (A. flavus) $\left(0,2 \times 10^{-6} \mathrm{CFU} / \mathrm{mL}\right)$. Berdasarkan hasil yang telah diperoleh, dapat dinyatakan bahwa penurunan jumlah populasi jamur tanah disebabkan karena adanya kompetisi untuk nutrient dan ruang, adanya metabolit sekunder yang dapat menghambat jamur yang lain, dan lebih cepat mengabsorbsi nutrisi sehingga pertumbuhannya lebih cepat. Menurut Sudhakaran (2013), apabila kebutuhan nutrisi jamur dalam tanah terpenuhi maka populasinya akan meningkat. Begitupun menurut Winarso (2005), tingkat populasi jamur tanah dipengaruhi oleh ketersediaan makanan, ketersediaan air, dan ekologi lain yang mendukung.

Selain faktor di atas, keberadaan populasi jamur tanah dipengaruhi juga oleh adanya aplikasi fungisida yang dapat menurunkan jumlah jamur tanah. Penggunaan fungisida Mankozeb pada pertanaman kubis selama masa produksi, menyebabkan adanya akumulasi residu fungisida dalam tanah, sehingga terdapat kemungkinan adanya penurunan jumlah populasi jamur tanah akibat akumulasi residu fungisida Mankozeb tersebut. Irmawan (2007) menyebutkan bahwa dari hasil survei petani yang tidak melakukan penyemprotan pestisida ternyata keragaman dan kelimpahan jamur sangat tinggi.

Pendugaan dari Umboh (2016) tentang penurunan jumlah populasi jamur tanah karena adanya akumulasi residu pestisida dalam tanah selama aplikasi pestisida pada tanaman sayuran kubis, diungkapkan juga oleh Paul dan Clark (1997) dalam Humaidi (1999), bahwa penurunan jumlah populasi jamur tanah diduga disebabkan oleh tingginya penggunaan bahan aktif pestisida untuk tanaman dan tanah serta lambatnya tingkat degradasi bahan aktif tersebut di dalam tanah. Lebih lanjut menurut Deacon (1997) dalam Humaidi (1999), rendahnya jumlah populasi jamur tanah diduga karena propagule (konidia) mengalami dormansi (resting spores).

Hasil pengamatan nilai rerata kelimpahan jamur tanah pada 5 perlakuan $(A-E)$ diperoleh nilai rerata kelimpahan spora (CFU/mL). yang tertinggi pada sampel $A$ terdapat pada isolat $\mathrm{KJ} 7$ ( $P$. citrinum) sebesar $2,1 \times 10^{-6} \mathrm{CFU} / \mathrm{mL}$ dan terendah pada isolat $\mathrm{KJ} 6(M$. hiemalis) sebesar $0,1 \times 10^{-6} \mathrm{CFU} / \mathrm{mL}$, sampel B terdapat pada isolat $\mathrm{KJ} 5$ (Penicillium sp.) sebesar $3,7 \times 10^{-6} \quad \mathrm{CFU} / \mathrm{mL}$ dan terendah pada isolat $\mathrm{KJ} 7$ ( $P$. citrinum) sebesar $0,06 \times 10^{-6} \mathrm{CFU} / \mathrm{mL}$, sampel C terdapat pada isolat $\mathrm{KJ} 5$

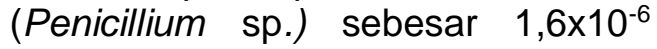
$\mathrm{CFU} / \mathrm{mL}$ dan terendah pada isolat KJ3 ( $T$. harzianum) sebesar $0,07 \times 10^{-6}$ $\mathrm{CFU} / \mathrm{mL}$, sampel $\mathrm{D}$ terdapat pada isolat yaitu $\mathrm{KJ} 5$ (Penicillium sp.) sebesar $1,9 \times 10^{-6} \quad \mathrm{CFU} / \mathrm{mL}$ dan terendah pada isolat $\mathrm{KJ} 2 \quad(C$. sytophila) sebesar $0,04 \times 10^{-6} \mathrm{CFU} / \mathrm{mL}$, dan pada sampel $\mathrm{E}$ terdapat pada isolat $\mathrm{KJ} 5$ (Penicillium sp.) sebesar $5,9 \times 10^{-6} \mathrm{CFU} / \mathrm{mL}$ dan terendah pada isolat $\mathrm{KJ} 6(M$. hiemalis) sebesar $0,06 \times 10^{-6} \quad \mathrm{CFU} / \mathrm{mL}$. Hasil ini menunjukkan bahwa populasi spora jamur tanah pada sampel $D$ lebih rendah dibandingkan pada sampel yang lainnya. Hal ini diduga karena pengaruh adanya penyemprotan fungisida Mankozeb yang sudah berlangsung lama dilakukan petani dilahan pertanaman kubis, mengingat residunya bersifat racun terhadap mikroorganisme, khususnya jamur tanah.

Penurunan jumlah populasi jamur tanah pada penelitian ini menunjukkan bahwa aplikasi fungisida Mankozeb dapat 
mempengaruhi jumlah jamur tanah. Perubahan ini juga dikemukakan oleh Sa'id et al. (1994), bahwa insektisida Deltametrin secara nyata menurunkan jumlah jenis dan populasi mikroorganisme tanah. Hasil ini sejalan dengan penelitian yang dilakukan oleh Subowo (2012), ternyata konsentrasi Deltametrin berkisar 50 ppm - 300 ppm (mg/L) dapat mempengaruhi jumlah jamur Aspergillus, Penicillium, dan Tricoderma. Menurut Nare et al., (2010), aplikasi pestisida di lahan pertanian akan menghambat aktivitas mikroba tanah. Dapat dilihat dengan adanya penurunan aktivitas respirasi dan penurunan pembentukan biomassa pada aplikasi Endosulfan di lahan.

\section{KESIMPULAN}

Berdasarkan hasil penghitungan jumlah koloni dan rerata jumlah spora/mL, fungisida Mankozeb mempengaruhi jumlah populasi jamur tanah, dari 6 famili dengan 11 spesies yang ditemukan, jamur tanah yang memiliki koloni terbesar adalah isolat KJ5 (Penicillium sp.) sebesar 270 koloni dengan kisaran jumlah spora $5,9 \times 10^{-6} \mathrm{CFU} / \mathrm{mL}$ dan terendah pada isolat $\mathrm{KJ} 3$ ( $T$. harzianum) sebesar 2 koloni dengan jumlah spora $10^{-7} \mathrm{CFU} / \mathrm{mL}$.

\section{DAFTAR PUSTAKA}

Hindersah R, Rachman W, Fitriatin BN, Nursyamsi D (2014) Populasi Bakteri dan Jamur pada Rizosfer Caisim (Brassica juncea L.) yang Ditanam di Tanah Dikontaminasi Insektisida Organoklorin Setelah Aplikasi Konsorsia Mikroba dan Kompos. Agrologia 3(2):75-82

Humaidi F, Latief A, Abadi, Siti, Rasminah CS (1999) Tingkat Residu Fungisida Methyl Thiophanate Dalam Tanah Pada Tanaman Kentang Serta Dampak Terhadap Kehidupan
Jamur Tanah Di batu Malang. http://www.peipfi-komdasulsel. org/wp-content/uploads/2012/ 04/Faisol-Humaidi-TingkatResidu-Fungisida-MethylThiophanate-Dalam-TanahPada-Tanaman-Kentang-SertaDampak-Terhadap-KehidupanJamur-Tanah-Di-Batu-

Malang.pdf . Diakses pada 7 November 2017

Hoog S (2005) Essential Microbiology. John Wilet \& Sons, Inc. Chichester

Irmawan DE (2007) Kelimpahan dan Endofit pada Beberapa Varietas Padi di Tasikmalaya dan Subang. IPB, Bogor, Jawa Barat

Khan MZ (2003) Effect of Pesticides on Biodiversity: Comparison of Malathion with Biosal on Protein Contents in Calotes Versicolor. $J$ nat hist wildl 2(1):25-28

Nare RWA, Savadogo PW, Gnankambary Z, Sedogo P (2010) Effect of Endosulfan, Deltametrin and Profenofos on Soil Microbial Respiration Characteristics in Two Land Uses Systems in Burkina Faso. Research of Environ Sci 4(3):261-270

Noya Al (2004) Residu Insektisida Profenofos pada Sayuran Kubis dan Tanah Andosol Rurukan Kecamatan Tomohon. Tesis. Program Pascasarjana Universitas Sam Ratulangi. Manado

Pangestu D (2009) Isolasi, Identifikasi, Dinamika dan Skrining Pertumbuhan Jamur dari Biokonversi Palm Kernel Meal. Makalah I. FMIPA UI, 2009.http://lontar.ui.ac.id/file?fil $\mathrm{e}=$ digital/130041-T\%2027083Isolasi,\%20identifikasi-Analisis. pdf. Diakses pada 20 Maret 2018

Rao NSS (1994) Mikroorganisme Tanah dan Pertumbuhan 
32 JURNAL BIOSLOGOS, FEBRUARI 2018, VOL. 8 NOMOR 1

Tanaman. Terjemahan: Herawati Susilo. UI-Press, Jakarta

Sa'id EG (1994) Dampak Negatif Pestisida, Sebuah Catatan bagi Kita Semua. Agrotek 2(1):71-72

Sembel DT (2014) SeranggaSerangga Hama Tanaman Pangan, Umbi dan Sayur. Penerbit Bayumedia publishing, Malang

Subowo YB (2012) Seleksi Jamur Tanah Pendegradasi Selulosa dan Pestisida Deltamethrin dari Beberapa Lingkungan di Kalimantan Barat. J Tek Ling 13(2):221 - 230

Sudhakaran M, Pamamoorthy D, Kumar SR (2013) Impact of Conventional, Sustainable and Organic Farming System on
Soil Microbial Population and Soil Biochemical Properties, Puducherry, India. International J Environ Sci 4(1):28-41

Umboh S (2016) Analisis Kadar Residu Pestisida dan Bioakumulasinya Terhadap Laba-laba Predator, Fisikokimia dan Biologi Tanah di Pertanaman Sayuran Kubis. Disertasi. Pascasarjana Universitas Sam Ratulangi, Manado

Wardhana WA (2001) Dampak Pencemaran Lingkungan. Penerbit ANDI, Yogyakarta Winarso S (2005) Kesuburan Tanah: Dasar Kesehatan dan Kualitas Tanah. Gava Media, Yogyakarta 